\title{
Petrography and Geochemical Characteristics of Nari Sandstone in Lower Indus Basin, Sindh, Pakistan
}

\author{
Abdul Majeed Shar1, Aftab Ahmad Mahesar², Asad Ali Narejo ${ }^{3 a}$, Noor Fatima ${ }^{3 b}$
}

RECEIVED ON 11.03.2019, ACCEPTED ON 26.07.2019

\begin{abstract}
Pakistan has been suffering from severe energy crisis for decades. Discovering new oil and gas fields plays significant role in alleviating the energy deficit. Exploitation and development of new fields for the country is very challenging due to economic, technological, social and environmental concerns. Hence, it is essential to assess the potential of hydrocarbon bearing formations using integrated analysis techniques in order to explore the resources efficiently. In this paper, we have analyzed Nari sandstone reservoir potential of the country. The key objectives of the study are to characterize petrographic, mineralogical and microstructural data through laboratory study on Oligocene strata of Nari sandstone in the lower Indus Basin. For this purpose, we collected several exposed outcrop samples from different stations in the onshore areas of Nari Sandstone formation. The work performed includes, the integrated study of petrography using Scanning Electron Microscopy (SEM) along with Energy Dispersive Spectrometry (EDS) application. In addition, Quantitative X-Ray Diffraction (QXRD) analysis was performed. The results revealed that these sandstones were mainly composed of quartz grains, which are surrounded by calcite cement. EDS elemental sequence shows Calcium (Ca), Carbon (C), Silicon (Si), Iron ( $\mathrm{Fe}$ ), Magnesium (Mg), Aluminum (AI) and $\mathrm{K}$ (Potassium) in variable intensities in the samples indicating the presence of different minerals within these rocks such as quartz, calcite, clay and ferruginous cement. This study is the comprehensive collection of data of Nari sandstones that is essential to assess the potential of hydrocarbon bearing formations.
\end{abstract}

Keywords: Mineralogy, Characterization, Petrography, Nari formation, Lower Indus Basin.

\section{INTRODUCTION}

$\mathrm{P}$ akistan's rapid population growth and urbanization on massive scale has resulted in large demand for energy [1-2]. Country currently is facing big challenge to alleviate the energy deficit and provision of sustainable supply of energy [2-3]. As the population of countries grows, the fields which are currently producing would not fulfill the upcoming energy requirements. To cope with such future energy demand, indigenous energy resource exploitation of the country offers rich rewards. Pakistan's major part of present energy source primarily is reliant on the fossil fuel which is relatively cheaper source of energy [4]. Though, the country will remain dependent on fossil fuels in upcoming years as the renewables have recently emerges in a very small quantity. Pakistan is rich in both conventional and unconventional hydrocarbon resources [5-7]. Pakistan's most of the sedimentary basins possess

${ }^{1}$ Department of Petroleum Engineering, NED University of Engineering and Technology, Karachi, Pakistan. Email: majeed99pg@gmail.com (Corresponding Author).

${ }^{2}$ Institute of Petroleum and Natural Gas Engineering, Mehran University of Engineering and Technology, Jamshoro, Pakistan. Email: engr.aftabmahesar@gmail.com

${ }^{3}$ Ministry of Energy, Petroleum division, Geological survey of Pakistan. E-mail: ageologist.asadali@gmail.com, bnoorcheema93@yahoo.com

This is an open access article published by Mehran University of Engineering and Technology, Jamshoro under CC BY 4.0 International License. 
significant reserves of oil and gas in both offshore and on shore areas; however, the country suffers from the lack of advanced technology and poor policy practices [3].

According to the US Agency for International Development (USAID) the unconventional gas resources of Pakistan are more than 10,000 tcf only from shale gas that are yet unexploited [8]. The shale oil also exists in huge quantity in country. The existence of around 206 tcf of gas as a hydrocarbon potential is present within the lower Indus Basin as reported by US Energy Information Agency [8]. Further, the assessments were conducted on refinement of data regarding indigenous resources potential. The studies have reported that technically recoverable amounts of reserves of from these hydrocarbon reservoirs are huge to be developed to cope-up with the energy demand. Hence, it is essential to search those hydrocarbon targets which are yet unexplored in order to meet the increasing demand of energy. It commonly held that the hydrocarbon potential in the lower Indus basin Nari formation of Oligocene has shown very good reservoir potential [9] comprising of the sandstones and shales along with subordinate limestones and minor amounts of conglomerates [9-10]. Moreover, it is worth to note that silt beds of Nari Formations especially in coastal offshore areas possess very good potential for natural gas generation [10-12]. Nari formation hydrocarbon potential lies under the lower Indus basin, which encompasses around between latitude of $23^{\circ}$ and $28^{\circ} 31^{\prime} \mathrm{N}$, and from longitude of $66^{\circ} \mathrm{E}$ to the eastern boundaries of Pakistan [11]. Pakistan's several producing fields in particular the offshore areas are mainly the Nari formation sandstones, having potential hydrocarbon bearing targets. Despite the fact that Oil \& Gas exploration E\&P companies along with their joint exploration shareholders and joint partners in past (e.g. Occidental of Pakistan Inc., and OGDC (Oil and Gas Development Corporation) discovered hydrocarbon reserves within Nari sandstones reservoirs [9]. These companies have discovered many oil and gas fields and wells been drilled in sedimentary basin of Pakistan. However, the huge potential of oil and gas reserves still exists and unexplored within lower Indus basin Pakistan, due to the lack of the technological advancements. Hence, it would be far better to do detailed assessment of target reservoirs that will help in reducing the risk associated and to increase the investment opportunity. It is also been reported that the Nari formation has remained key exploration target in both onshore and offshore area [10-11]. To date, few studies have been conducted to evaluate Nari sandstones reservoir potential [10]. These studies have provided information on fewer characteristics of the reservoir rock properties. Generally, these have characterized rocks at macroscopic scale i.e. the source rock potential and hydrocarbon accumulation. Although; characterization on microscopic scale is difficult but is essential in order to better understand the reservoir quality. Additionally, for successful development of any fields and their production optimization at commercial rates it is essential to do in-depth analysis for understanding reservoir characteristics in order to develop new ventures appropriately. Moreover, it is worth to noted that for successful development of any reservoir understanding of their petrophysical properties is essential including rock porosity, pore structure, pore size and rock permeability. Although, many previous studies on Nari sandstones from lower Indus basin Pakistan have mostly focused on assessing the accumulation, deposition and stratigraphic settings and evaluated source rock [10-11]. However, the sandstones of Nari formation discovered in Pakistan, there is not enough work which has been done on their petrography and geochemistry to date. Therefore, present study analysis is centered on the petrographical observation and geochemical investigation. Hence, in this regard we collected outcrop samples from different locations of Nari Sandstones in the lower Indus basin, Sindh, Pakistan. Further, the work performed is an extensive analysis on mineralogy, microstructure depositional environment and other geological parameters that influences the quality of hydrocarbon potential of Nari sandstone reservoir. The experiments conducted include the mineralogy and microstructural analysis using XRD (X-Ray Diffraction) technique, SEM (Scanning Electron Microscopy) and thin sections were prepared for petrographic analysis. The obtained information will help to understand the reservoir potential of the lower Indus Basin and to reduce the risk and to increase the investment opportunities. 


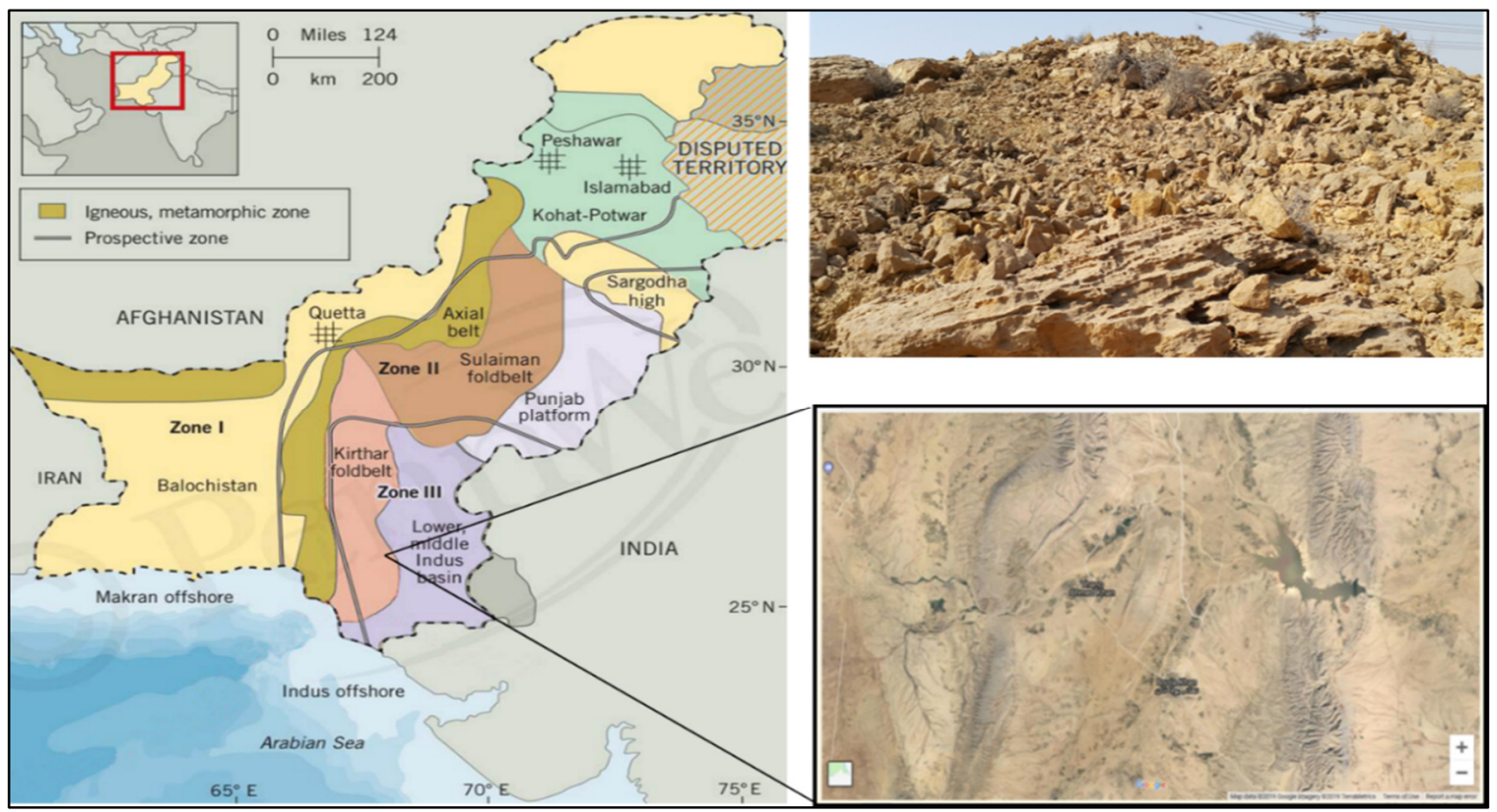

Fig. 1: The Study area exposed in between Thana Bola Khan and Thana Ahmed Khan north-east of Karachi Metropolis, The upper right photo is the image of field and the lower right is taken from Googlemaps ${ }^{\mathrm{tm}}$, 2019 (Map Modified From Shar et al. [2]).

\subsection{Regional Geology of the Study Area}

The data analyzed in this study included, the outcrop samples that were collected from north-east of Karachi metropolis and the exposed area lies between the city of Thana Bola Khan and Thana Ahmed Khan (Fig. 1). This area is intensely deformed and is the part of southern Kirthar fold belt where North-South running alternating anticlines and synclines form the ridges and depressions respectively [12]. Stratigraphically, surrounding area strata mostly vary in age from lower Eocene to Miocene age rocks with older rocks being exposed in the cores of anticlines and younger strata is exposed at synclinal depressions. We have collected more than clastic samples from the lower part of Nari formation exposed and overlain on the Tiyon formation [12-13]. Nari Formation is exposed at N-W dipping flank of Asymmetrical Surjan Anticline about $5 \mathrm{~km}$ before the Thana Ahmed Khan city. Other seven clastic samples were collected from the Nari formations that are exposed on the west dipping flank of an Anticline near Thana Ahmed Khan city, where Nari Formation is overlain on the Eocene Kirthar Formation. All samples at different stations were taken from the oldest Tobo member of Nari formation.

\section{MATERIALS AND METHODS}

An integrated microstructural, mineralogical and petrographic study of the Nari sandstone (Tobo Member) in the Lower Indus basin of encompassing the district Jamshoro Thana Bola Khan Sindh, Pakistan has been carried out. Several fresh exposed outcrop samples from lower Indus Basin Nari Formation of Oligocene strata near anticline structure were collected for this study. The details about the tests performed and number of samples analyzed are given in Table 1. The samples were characterized using XRD, SEM-EDS techniques. Powdered samples for XRD analysis were prepared as well as thin sections were prepared for petrographic study. The sandstones samples of Nari Formation from Lower Indus Basin were selected for detailed petrographic analysis using standard techniques. XRD analysis was done using Match and X-pert pro software. The petrography of selected four samples was carried out using Lieca optical microscope. The SEM images were obtained using Jeol Japan Compact fieldemission-SEM and X-Ray EDS. The detailed 


\begin{tabular}{|c|c|c|c|c|c|c|c|}
\hline \multicolumn{2}{|c|}{ Location } & Stations & Sample ID & $\begin{array}{l}\text { Quantitative X-Ray } \\
\text { Diffraction }\end{array}$ & SEM & $\begin{array}{l}\text { Thin } \\
\text { Section }\end{array}$ & EDS \\
\hline \multirow{5}{*}{$\begin{array}{c}\text { Lower } \\
\text { Indus Basin, } \\
\text { Sindh Pakistan }\end{array}$} & \multirow{3}{*}{$\begin{array}{l}\text { Group-A } \\
\text { Samples }\end{array}$} & Station-1 & 18-NR-01 & 01 & 01 & 01 & 02 \\
\hline & & Station-1 & 18-NR-02 & 01 & 01 & 01 & 01 \\
\hline & & Station-1 & 18-NR-03 & 01 & 01 & 01 & 02 \\
\hline & \multirow{2}{*}{$\begin{array}{r}\text { Group-B } \\
\text { samples }\end{array}$} & Station-2 & 18-NR-04 & 01 & 01 & 02 & 02 \\
\hline & & Station-2 & 18-NR-05 & 01 & 01 & 01 & 01 \\
\hline
\end{tabular}

petrographic analysis was conducted and almost all the visible grains in thin sections were observed. Visual percentages of different grains seen in thin sections were counted to perform modal analysis. Afterwards, quartz, feldspar and lithic fragments were recalculated in ternary percentage relations. In addition, different ternary diagrams were constructed by adopting the Folk et. al. [14], Suttner et. al. [15] and Dickinson et. al. [16] in the present study investigation. These

ternary diagrams will help in providing information about origin, depositional environment and tectonic settings in the region and information of the paleoclimate of source area. The details about the individual procedures followed are described below separately.

Petrographic Analysis: Once the samples were obtained from the area of interest it is essential to perform petrographic study of these samples. This was performed using the Lieca optical microscope in order to perform petrology and optical mineralogy to identify rocks and minerals within these prepared/selected thin sections.

Mineralogical and Microstructural Analysis: The microstructural and mineralogical analysis was performed for the selected samples from Nari sandstone formation. For this reason argon ion beam milling was used to provide flat surfaces for highmagnification imaging. A Jeol Japan Compact fieldemission- SEM and X-Ray EDS at centralized sciences laboratory and the facility available at Geological Survey of Pakistan microscope was used to observe microstructure and mineralogy of the samples collected from Nari formation.

Quantitative X-Ray Diffraction Analysis: A broad range of XRD facility available has the capabilities for phase identification, phase characterization and texture analysis. This laboratory facility allows for analysis of compounds in various types of samples such as in cements, soils, etc. determination within different constituents.

\section{RESULTS AND DISCUSSIONS}

\subsection{Petrography}

Petrography of sedimentary rocks supports in understanding the geological past history giving the signs about the source rock, depositional environment, diagenetic history, and tectonic settings [17]. Petrography also plays a vital role in assessing and interpreting the other tests such as XRD tests. Petrographic observations on microscopic level examine the weathered and altered particles of the rocks in the specimen [17]. In this study several samples for petrography were analyzed. Overall, the texture of the studied samples reveals that most of the sandstones are moderately to poorly sorted and mineralogically semi-mature. Further, it was observed that on average, the quartz in these samples varies between $55-65 \%$ and the rest is occupied by calcareous matric, ferric and calcite cement and grains such as feldspars and rock fragments. The cementing materials in studied samples are ferric oxide and calcite meniscus. Quartz crystals are both monocrystalline and polycrystalline in character. Although, the minerals such as, monocrystalline quartz is dominant in quantity than polycrystalline within studied samples. The quartz crystals are highly fractured at some places showing deformation has occurred due to tectonic activities or may be due to the grains sliding and lithification. The deformation and fractured nature of these grains shows intense tectonic deformation locally within this Nari formation sandstone samples. 
Each sample analysed is shown in Fig. 2(a-f) and the detailed petrographic description of each sample studied is provided Table 2. From thin section petrography analysis in Sample in Fig 2(a) reveals that at the extreme left and bottom right are lithic fragments along with fine grain Qtz (Quartz) crystals. The quartz grains were cemented with calcite and ferric cement. The sample in Fig. 2(b) shows that at the centre is alkali feldspar grain surrounded by quartz grains and are cemented by calcite and iron oxide cements. Compositionally, the Nari sandstone sample in Fig. 2(c) shows that at centre there is plagioclase grain surrounded by quartz grains and cemented by iron oxide and with calcite cement. The thin section petrography analysis of sample in Fig. 2(d) shows that ooids are present along with medium sized quartz grains and cemented by $\mathrm{Fe}$ and calcite. The sample in Fig. 2(e) shows that minerals observed from thin section are dominated by quartz crystals with alkali feldspars at the top centre in the carbonate mud matrix. The petrographic analysis of sample in Fig. 2(f) suggests that the Qtz is the dominating mineral however, on the top right of the image shows grey colored lithic fragment that is surrounded by cementing materials such as iron oxide and calcites.

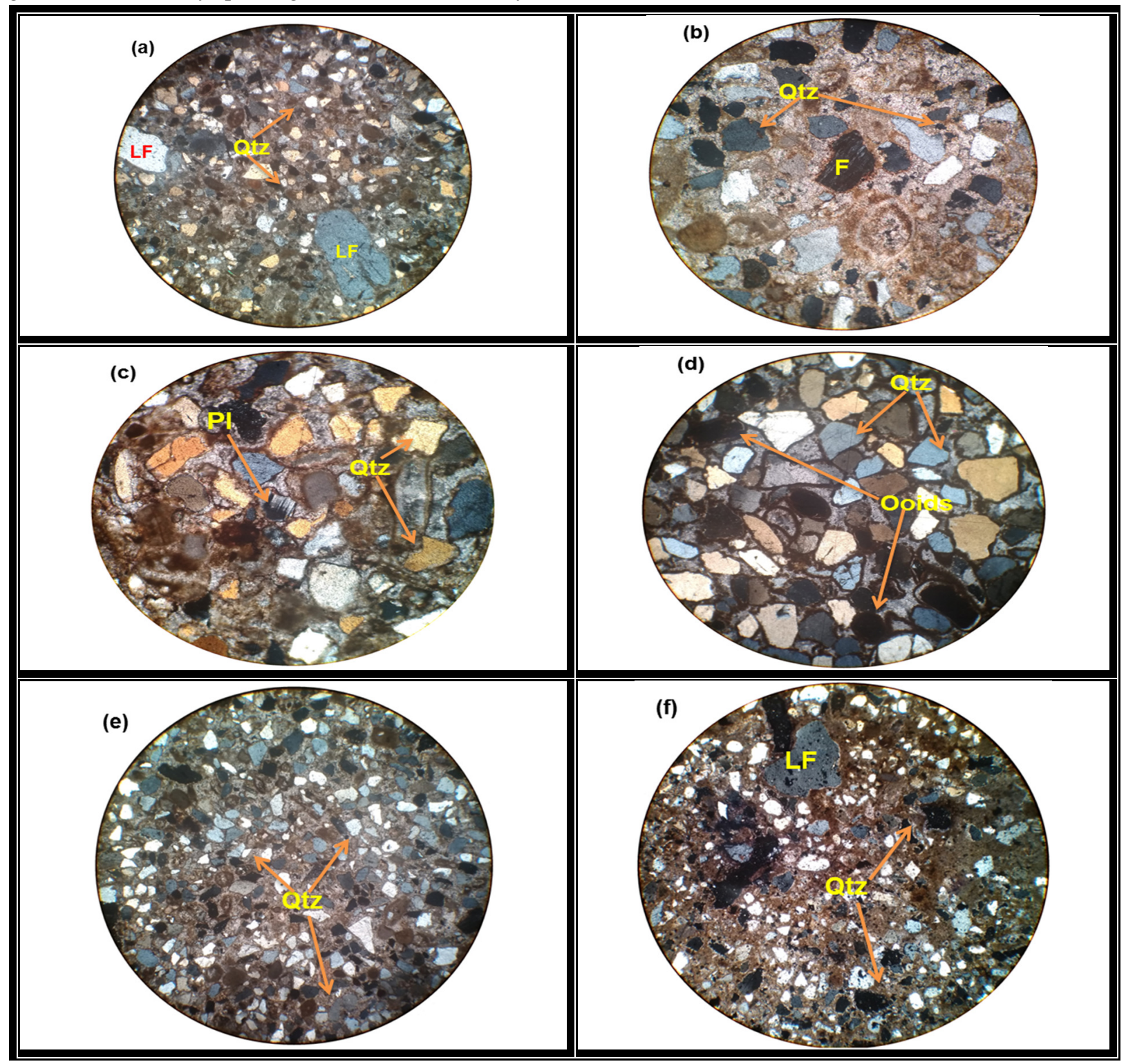

Fig. 2: Detailed Petrographic Description of the Nari sandstone samples. All photographs are taken in XPL and magnification is $40 \mathrm{x}$ 


\begin{tabular}{|c|c|c|c|c|}
\hline No. & Sample ID & Rock Class/Type & Rock Class & Description \\
\hline 1. & 18-NR-01 & $\begin{array}{c}\text { Calcareous } \\
\text { Sandstones of } \\
\text { Nari formation }\end{array}$ & Sedimentary & $\begin{array}{l}\text { This sample is calcareous arkose sandstone. The grain arrangements as } \\
\text { observed from thin section were poorly to moderately sorted. It is } \\
\text { composed of fine to medium grained quartz crystal. These quartz crystals } \\
\text { are angular, sub-angular to sub-round. Quartz crystals are cemented by } \\
\text { calcite and ferric oxide. These sandstones contain about } 65 \% \text { quartz grains } \\
\text { with few lithic fragments, plagioclase. At some places ooids as shown in } \\
\text { figure } 2 \text { (d) are present with the matrix showing carbonate mud influx } \\
\text { during deposition. Bivalve shell filled with sparry calcite. }\end{array}$ \\
\hline 2. & 18-NR-02 & $\begin{array}{c}\text { Calcareous } \\
\text { Sandstones of } \\
\text { Nari formation }\end{array}$ & Sedimentary & $\begin{array}{l}\text { It is calcareous, ferruginous arkose sandstone. This study revealed poor to } \\
\text { moderately sorted and fine to medium grained. Quartz crystals are sub- } \\
\text { angular to sub-rounded. These quartz crystals are cemented by iron oxide } \\
\text { and calcite meniscus cement. These samples show almost } 55 \% \text { are quartz } \\
\text { grains including few polycrystalline quartz grains, lithic fragments, and } \\
\text { alkali feldspar in Figure } 2 \text { (b). Quartz crystals are highly fractured at places } \\
\text { showing deformation. Few forams shells are also observed in the sample. }\end{array}$ \\
\hline 3. & 18-NR-03 & $\begin{array}{l}\text { Calcareous } \\
\text { Sandstones of } \\
\text { Nari formation }\end{array}$ & Sedimentary & $\begin{array}{l}\text { This sample is calcareous arkose sandstones, poorly to moderately-sorted. } \\
\text { Fine grained. Quartz crystals are angular, sub-angular to sub-round. } \\
\text { Quartz crystals are cemented by Fe oxide and calcite cement. Quartz } \\
\text { grains in these samples observed are around } 60 \% \text { including few } \\
\text { polycrystalline quartz grains, lithic fragments as shown in Figure } 2 \text { (f). } \\
\text { Many quartz crystals show undulatory extinction. }\end{array}$ \\
\hline 4. & 18-NR-04 & $\begin{array}{c}\text { Calcareous } \\
\text { Sandstones of } \\
\text { Nari formation }\end{array}$ & Sedimentary & $\begin{array}{l}\text { These sandstones are poorly to moderately sorted, slightly medium to fine } \\
\text { grained. In this rock, quartz grains are sub-angular to sub-round. Quartz } \\
\text { crystals are cemented by Fe oxide and calcite cement. Around } 60 \% \text { are } \\
\text { quartz grains including some polycrystalline quartz grains, lithic } \\
\text { fragments and plagioclase as shown in Figure } 2 \text { (c). Iron concretions and } \\
\text { Rims of ferruginous material and left over pore spaces are filled with spray } \\
\text { calcite. }\end{array}$ \\
\hline
\end{tabular}

\subsection{Mineralogy and Microstructure}

An integrated study of mineralogy and microstructural analysis of the Nari sandstone samples conducted shows that the grains in these sandstones are medium to fine-grained, angular to sub angular and poor to moderately-sorted. Cementing materials were observed in these samples are calcareous and ferruginous cements. Texturally, the grain size varies from fine grained to medium grained, grain shape from angular, sub-angular to sub-round, and sorting character varies from poor to moderately-sorted. Qtz crystals are cemented by calcite meniscus and ferric oxide cement (Fig. 3). The modal analysis in petrography revealed that around 55-65\% Qtz grains are present within these studied samples with 1-3\% alkali feldspar and plagioclase, 1-2\% lithic fragments, and remaining part is filled with sparry calcite, ferriccalcareous mud and cements. Authigenic chlorite, illite and semtite in minor quantity were identified by SEM image analysis in few of these sandstones. This illite-semctite was identified by SEM image analysis (Fig. 3) and was confirmed by Q-XRD analysis (Fig. 4). The detailed descriptions of features observed from each analyzed sample are provided below separately.
EDS profiles of all analyzed samples could be seen in Fig. 5.

Sample-18-NR-1: Calcareous arkose sandstone, fine to very fine-grained, angular to sub-rounded and poorly sorted. SEM image analysis of this sample (Fig. 3) photomicrograph shows the quartz grains are surrounded by calcite. EDS (Fig. 5) also confirmed the calcites through $\mathrm{Ca}$ and $\mathrm{C}$ peaks indicating calcite, $\mathrm{Si}$ indicate quartz, $\mathrm{Fe}$ is due to the iron cement in the rock and $\mathrm{Mg}$ may be part of calcite. Other associated elements are such as, $\mathrm{Al}$ and $\mathrm{K}$ may show intermixed clay content.

Sample-18-NR-2: From SEM photomicrograph (Fig. 3) upper right image shows that the quartz is dominating mineral and the grains of Qtz are surrounded by calcite cement. Further EDS analysis performed that also confirms the mineralogy as observed from SEM image analysis. In this sample the EDS peaks showed that $\mathrm{Ca}$ and $\mathrm{C}$ were indicating calcite, $\mathrm{Si}$ indicate quartz, Fe peak on the EDS chart is the sign of iron oxides that acted as cementing materials in the rock and $\mathrm{Mg}$ may be part of calcite. 
The $\mathrm{Al}$ and $\mathrm{K}$ peaks on EDS chart may show intermixed clay content.

Sample-18-NR-3: This Sample, photomicrograph (Fig. 3) bottom left shows that the quartz is mainly covered by calcite. Although some Qtz grains observed are cemented in between calcite. The EDS analysis shows exactly the $\mathrm{Ca}$ and $\mathrm{C}$ of calcite, $\mathrm{Si}$ for Qtz and the Al mainly shows the clay impurity and $\mathrm{Mg}$ may be of calcite. In some places the SEM image shows that the covering surface is occupied by clay which is overlain on the quartz in calcite cement.

Sample-18-NR-4: The bottom right Sample-18-NR04 in SEM photomicrograph shows that the most of the composition of this is Qtz. The quartz crystals are clear from the SEM image (Fig. 3 bottom right). EDS analysis shows that $\mathrm{Si}$ indicating the largest peak by $\mathrm{SiO} 2$ (Qtz), Al for clay, very minor values of $\mathrm{Ca}$ and $\mathrm{Fe}$ indicate calcite and Ferric cement occurrence respectively.
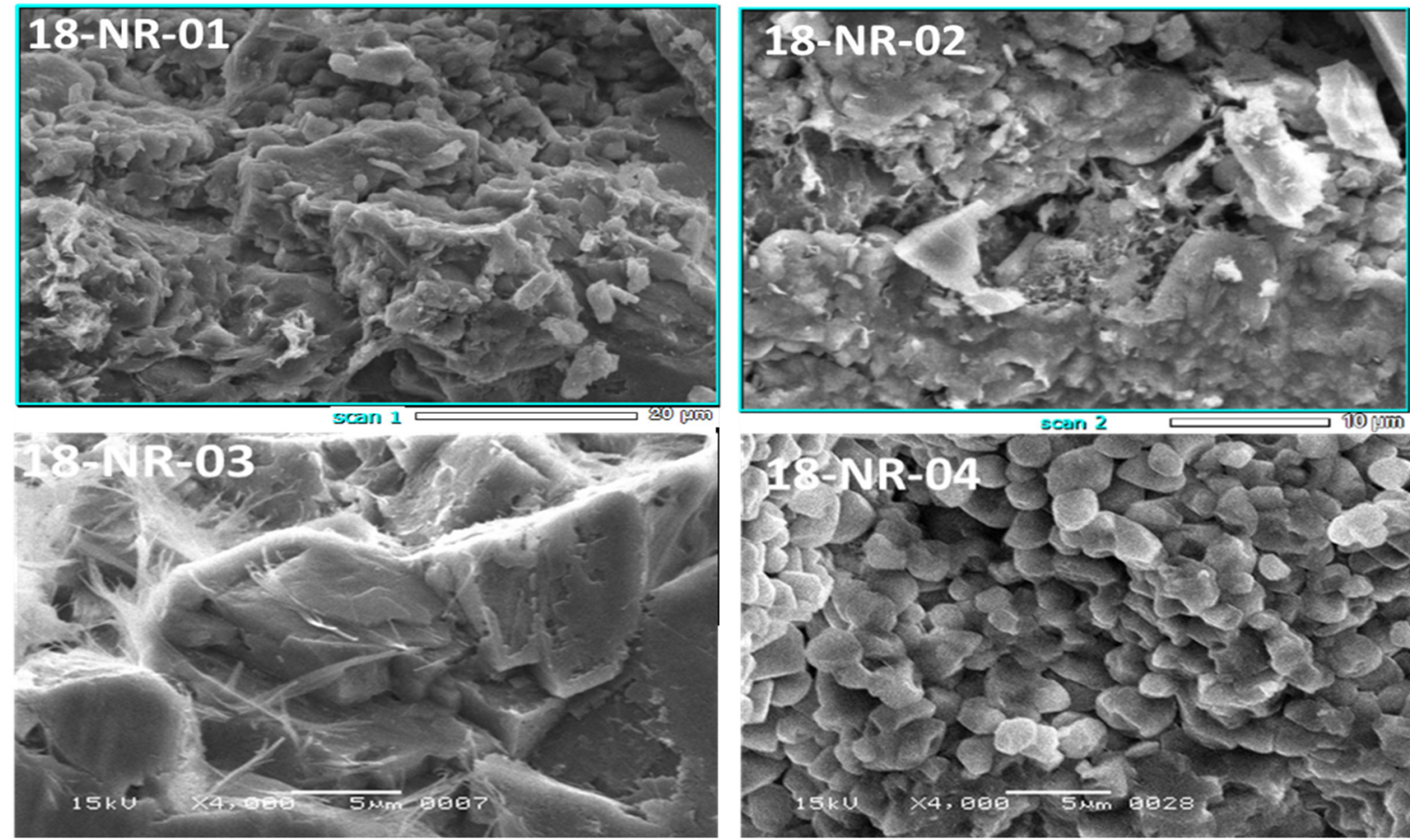

Fig. 3: SEM Photomicrograph of Nari Formations, The Results show the dominant minerals as (Ca), (C), (Si), (Fe), (Mg), (Al) and (K)
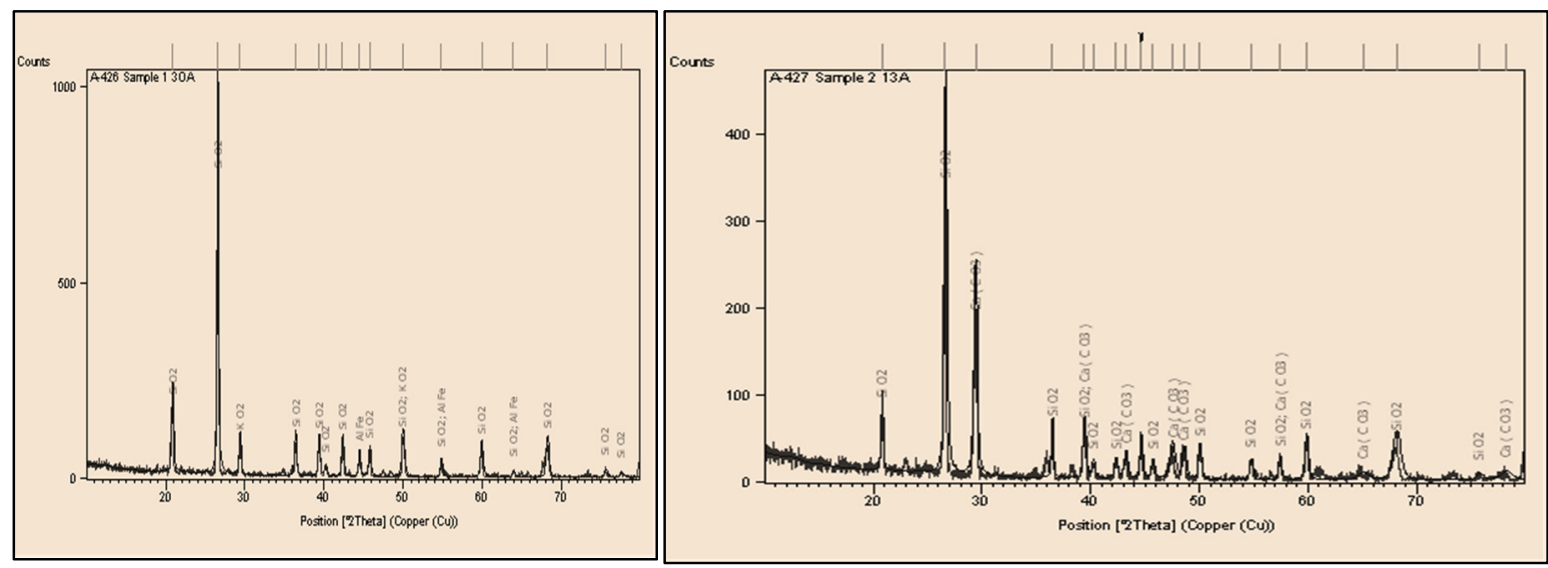

Fig. 4: Bulk Powdered XRD Profile Data of the two samples from Nari Formation sands 


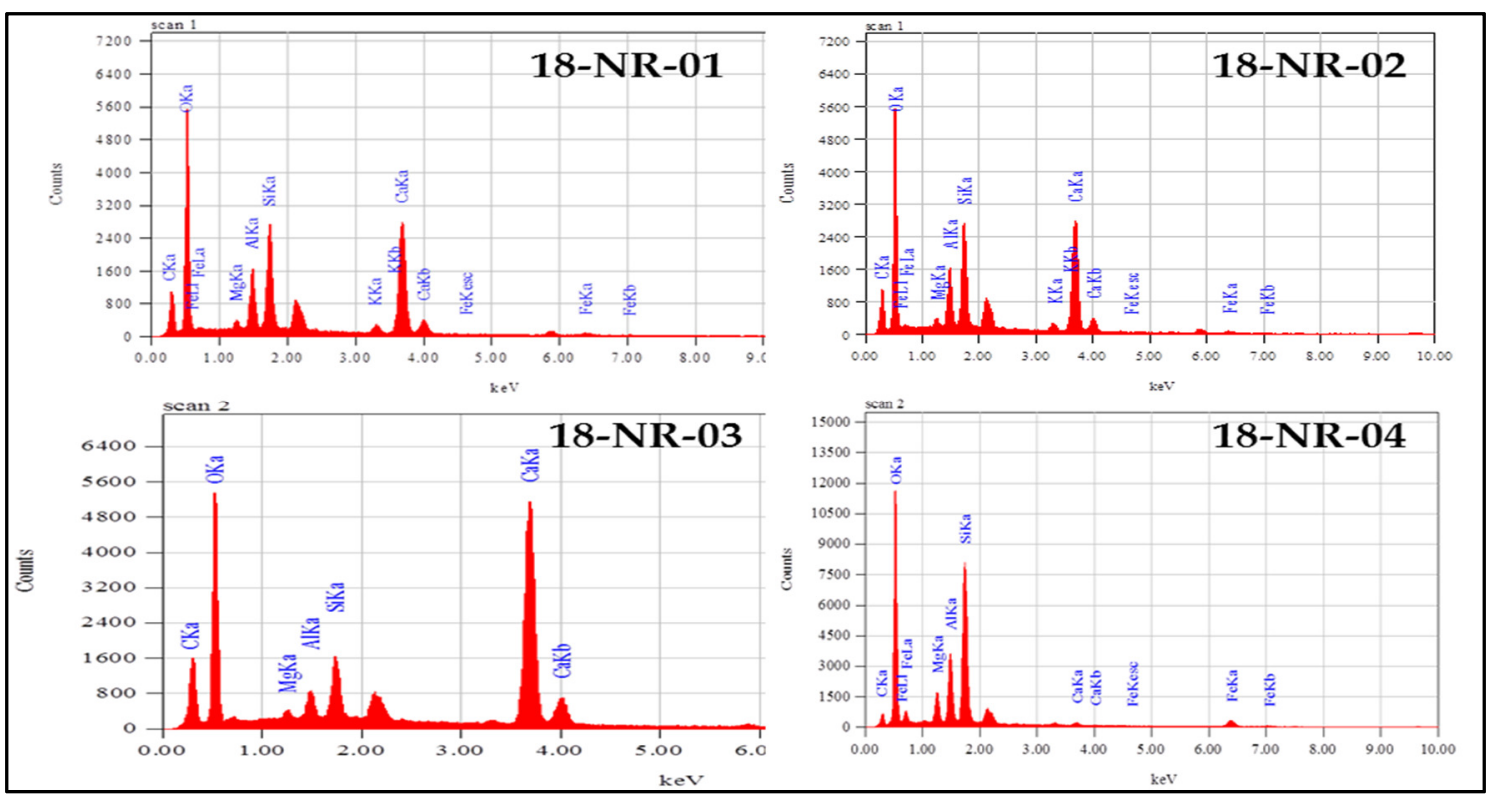

Fig. 5: SEM-EDS Pattern Data Showing the Elemental Compositions of the Samples Studied

\section{DISCUSSION}

An integrated study of mineralogy and microstructure of the Nari sandstone samples exposed in the area of Thana Bola Khan was conducted. Texture of the samples as seen under polarized microscope was mostly fine to medium grained, angular to subrounded and poorly to moderately-sorted. The thin section studies and SEM image analysis have shown that the Qtz crystals are cemented by Ferric oxide and calcite. These samples are composed of 55-65\% of Qtz grains including few polycrystalline Qtz grains, lithic fragments, and alkali and plagioclase feldspar. This petrographic analysis is supported by the SEM-EDS results as ( $\mathrm{Si}$ ) silica indicating quartz content, $\mathrm{Ca}, \mathrm{Mg}$ and $\mathrm{C}$ elements show the calcite as mud and cement, $\mathrm{Fe}$ indicate ferric cement and $\mathrm{Al}$ and $\mathrm{K}$ show clay content. The QXRD data shows similar mineral composition of the studied samples and closely match with results of petrographic studies and SEM-EDS analysis. We have observed that the silicate cement is present most of the samples analyzed, this reveals that the samples with moderate to poor sorting are expected to have poor permeability and porosity that affects the reservoir quality. However, the changes of grain sorting and arrangement have impact on the reservoir quality and the grain sorting and arrangement is dependent upon the extent by which these sediments were transported and deposited. Generally, the sediments, sand grains particles are well-rounded and well sorted shows the extensive sediment transport from longer transportation distance [18-19]. Nevertheless, the poorly sorted and sub-rounded sand grain deposition reflects smaller distance sediment transportation [18]. Present study Nari sandstones samples sediment transportation history proposes that the sediment deposited have the sub-rounded to subangular shapes and may have been deposited in cratonic basin. Further the thin section observations also indicated that there is an extensive reworking, implied a cratonic source [19]. The smaller amounts of lithic fragments and feldspars observed from thin sections also suggested that there was minor degree of chemical weathering have occurred and these sediments were part of cratonic basin. Further, it was seen that these Nari sandstone formation has went to some diagenetic processes resulting in formation of some clays minerals. In addition, the silicate cements in these sands were present through as observed from SEM images. The main reason of poor porosity and permeability of these sandstones is the existence of carbonate, calcite cements, which were identified from thin sections and SEM analysis. Moreover, the Nari sandstones samples studied were classified as ferruginous, calcareous-arkosic sandstone as observed from thin sections and interpreted by QFL ternary diagrams. The studied samples reveal that most of the sandstones are texturally less mature. The fractured nature of the quartz grains suggests that there might be the intense tectonic influence on the rock grains Mehran University Research Journal of Engineering and Technology, Vol. 40, No. 1, January 2021 [p-ISSN: 0254-7821, e-ISSN: 2413-7219] 
probably due to plastic deformation in surrounding geological province and this study area is the southern part of fault bounded Kirthar fold belt.

In past, various researchers have provided details in categorizing the tectonic settings and classification for the sedimentary rocks of the unknown basins $[18,20$ 25]. The QFL ternary diagrams (Fig. 6-7) were constructed adopting the Suttner et. al. [15], Dickinson et. al. [16] and Folks [14] approach to understand the source rock climate, tectonic setting and classification of sandstone respectively. The studied samples were interpreted that they may have deposited in the cratonic basin (Fig. 6). The source of that deposited material in the basin was most probably humid in climate and metamorphic in character (Fig. 6). Compositionally, the samples from the Nari sandstone can be classified as Sub-Arkose to Arkose in character owing to relatively higher percentage of feldspar in the samples (Fig. 7). It is also noted from the thin section studies that the boundaries between the crystals of polycrystalline quartz are sutured. This is the characteristic of quartz probably from a metamorphic source. The obtained mineral contents from present study analysis are provided in Table 3 . The dominating quantity of Qtz could be seen in the Table 3 along with other grains. Further, with the help of thin section analysis QFL ternary plots were constructed, which indicates that these sandstones are Sub-Arkose in character owing to relatively higher percentage of feldspar in the samples. Ternary plots adopted from folk [14] indicate that it is deposited in craton interior tectonic setting. The data plotted upon the Suttner $e t$. al. [15] ternary plot has indicated that the climate of source area of Nari formation was metamorphic humid nature (Fig. 7).

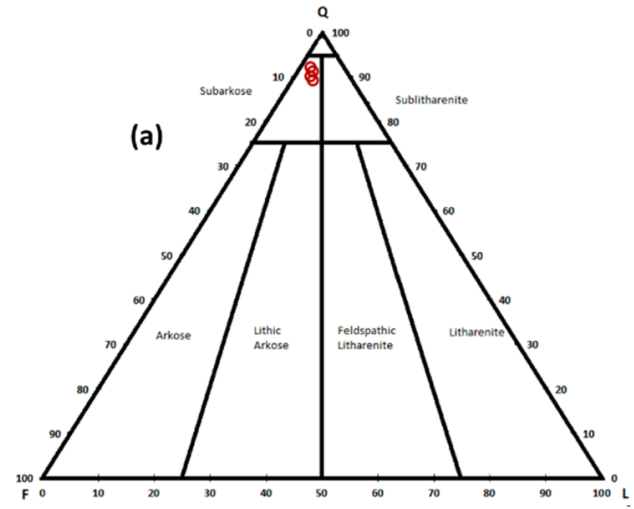

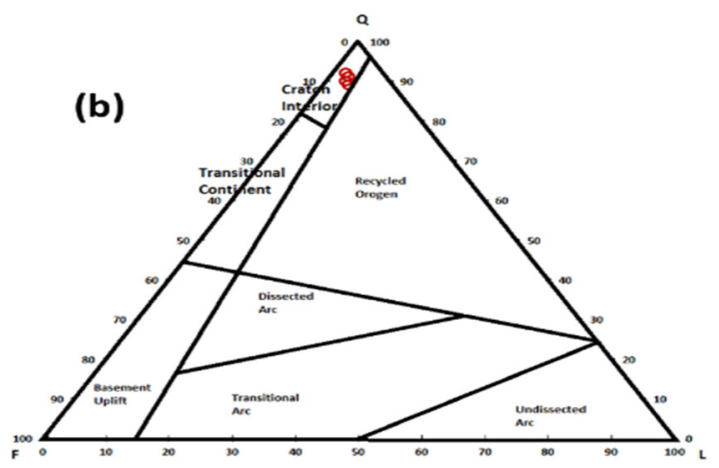

Fig. 6 (a) Quartz-Feldspars-Lithic (Qfl) Ternary Diagram of Nari Sandstone Sample Adopted From Folk (1974). (b) (QuartzFeldspars-Lithic) Ternary Diagram Showing the Sandstone Composition Adopted from Dickinson et. al. [16]

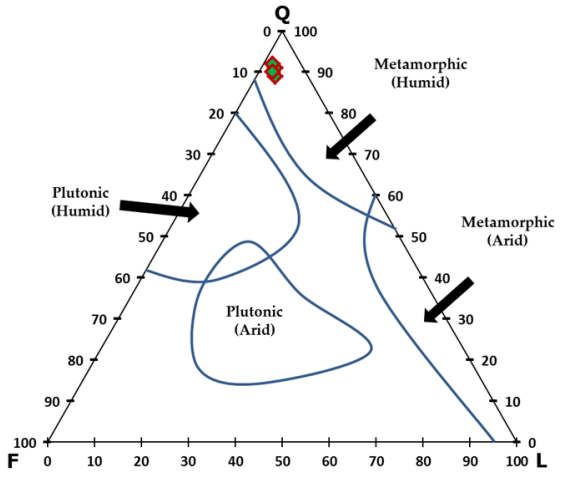

Fig.7: Source Rock Effect On Nari Sandstone, Modified After Suttner et. al. [15] Diagram

Table 3: The Recalculated Modal Composition of Quartz, Feldspar and Lithic Fragments of Nari Sandstone Samples.

\begin{tabular}{|c||c||c||c||}
\hline \hline Sample ID & $\begin{array}{c}\text { Quartz } \\
(\%)\end{array}$ & $\begin{array}{c}\text { Feldspars } \\
(\%)\end{array}$ & $\begin{array}{c}\text { Lithic } \\
\text { fragments } \\
(\%)\end{array}$ \\
\hline \hline 18-NR-01 & 91.00 & 6.00 & 3.00 \\
\hline \hline 18-NR-02 & 89.00 & 7.00 & 4.00 \\
\hline \hline 18-NR-03 & 92.00 & 6.00 & 2.00 \\
\hline \hline 18-NR-04 & 90.00 & 7.00 & 3.00 \\
\hline
\end{tabular}

\section{CONCLUSIONS}

An integrated study was conducted in order to assess the petrographic and mineralogical composition of the Oligocene strata of Nari sandstones in the lower Indus Basin, Pakistan. From this study the following conclusions were drawn,

(i) The sandstones of Nari Formation from lower Indus basin are classified as calcareous Arkose to Sub-Arkose sandstone owing to relatively higher 
percentage of feldspar in the samples as observed from petrographic studies.

(ii) The petrographic studies suggest mostly the samples are composed of medium to fine grained, angular to sub-rounded quartz, laths of feldspars, some lithic fragments along with broken fragments of fossils, cementing materials of iron oxides and calcites.

(iii) Thin-section analysis was confirmed from results of QXRD indicating that the Nari sandstone is mainly composed of quartz, feldspars, associated with some clay minerals and cements such as calcite and iron oxides.

(iv) The petrographic studies showed that these sandstones are comprised of medium to fine grained, angular to sub-rounded sorting indicating immature texture. Presence of clay minerals and calcite cements resulted in low permeability and porosity which indicates poor quality reservoir.

(v) Following diagram, the paleo-climate condition of source area of studied samples might be humid with mainly the metamorphic source rocks. The Nari sandstone could be the potential accumulation of hydrocarbons in particular to both on shore and offshore, as this possibly have substantial amounts for hydrocarbon generation.

\section{ACKNOWLEDGMENT}

First author would like to express thanks to NED University of Engineering \& Technology, Karachi, and Mehran University of Engineering \& Technology, Jamshoro, Pakistan, for providing the conducive environment. Other authors are grateful of the Ministry of Energy, Petroleum Division, Geological Survey of Pakistan. Potential Reviewers/Experts support is acknowledged for their critical review of the manuscript.

\section{REFERENCE}

[1] Ehsan M., Gu, H., Akhtar, M. M., Abbasi, S. S., and Ehsan, U., "A Geological Study of Reservoir Formations and Exploratory Well Depths Statistical Analysis in Sindh Province, Southern Lower Indus Basin, Pakistan," Kuwait Journal of Science, Vol. 45, No. 2, pp, 2018.
[2] Shar A. M., Mahesar A. A., and Memon K. R., "Could Shale Gas Meet Energy Deficit: Its Current Status and Future Prospects", Journal of Petroleum Exploration and Production Technology, pp, 1-11, 2017.

[3] Mirjat N. H., Uqaili, M. A., Harijan, K., Valasai, G. D., Shaikh, F., and Waris, M., "A Review of Energy and Power Planning and Policies of Pakistan", Renewable and Sustainable Energy Reviews, Vol. 79, pp, 110-127, 2017.

[4] Husain T., "Pakistan's Energy Sector Issues: Energy Efficiency and Energy Environmental Links", Lahore Journal of Economics, Vol. 15, 2010.

[5] Shar A. M., and Mahesar, A. A., "Pakistan's Kirthar Fold Belt Tight-Gas Reservoirs Show Development Potential", Oil and Gas Journal, Vol. 114, pp, 46-49, 2016.

[6] Mahesar A. A., Shar, A. M., Memon, K. R., and Baladi, S. A., "Experimental Study on Gas Slippage of Tight Gas Sands in Kirthar Fold Belt Sindh, Pakistan", Mehran University Research Journal of Engineering and Technology, Vol. 36, No. 3, pp, 719-732, 2017.

[7] Shar A. M., Mahesar, A. A., Chandio, A. D., and Memon, K. R., "Impact of Confining Stress on Permeability of Tight Gas Sands: An Experimental Study", Journal of Petroleum Exploration and Production Technology, Vol. 7, No. 3, pp, 717-726, 2017.

[8] Energy Information Administration (EIA), "World Shale Gas Resources: An Initial Assessment of 14 Regions outside the United States", U.S. Energy Information Administration, http://www.eia.gov/analysis/studies/worldshaleg as, 2011.

[9] Raza H. A., Ali S. M., and Ahmed, R., "Petroleum Geology of Kirthar Sub-Basin and Part of Kutch Basin", Pakistan Journal of Hydrocarbon Research, Vol. 2, No. 1, pp, 27-73, 1990.

[10] Mahmud S. A., and Sheikh, S. A., "Reservoir Potential of Lower Nari Sandstones (Early Oligocene) in Southern Indus Basin and Indus Offshore", Annual Technical Conference (ATC), pp. 7-8, 2009.

[11] Quadri, V. U. N., Shuaib S. M., "Hydrocarbon Prospects of Southern Indus Basin, Pakistan", AAPG Bulletin, Vol. 70, No. 6, pp, 730-747, 1986. 
[12] Humaira N., Usmani, P. A., and Lashari, R. A., "Planktonic zonation from the contact of Laki Formation (Early Eocene) and Tiyon Formation (Middle Eocene) Thana Bula Khan, Lower Indus Basin, Sindh, Pakistan", Journal of Himalayan Earth Sciences, Vol. 44, No. 2, pp, 17-23, 2011.

[13] Markhand A. H., Agheem, M. H., Warar, M. A., and Hakro, A. A., "Geochemical Investigations of Fuller's Earth Deposits around Thano Bula Khan Area, Sindh, Pakistan", Sindh University Research Journal-SURJ (Science Series), Vol. 43, No. 2, pp, 231-236, 2015.

[14]Folk R. L., Andrews, P. B., and Lewis, D. W., "Detrital Sedimentary Rock Classification and Nomenclature for use in New Zealand", New Zealand Journal of Geology and Geophysics, Vol. 13, No. 4, pp, 937-968, 1970.

[15] Suttner L. J., Basu, A., and Mack, G. H., "Climate and the Origin of Quartzarenites", Journal of Sedimentary Petrology, Vol. 51, pp, 235-246, 1981.

[16] Dickinson W. R., Beard, L. S., Brakenridge, G. R., Erjavec, J. L., Ferguson, R. C., Inman, K. F., Ryberg, P. T., "Provenance of North American Phanerozoic Sandstones in Relation to Tectonic Setting”, Geological Society of America Bulletin, Vol. 94, No. 2, pp, 222-235, 1983.

[17] Noori A., Rais S., "Geochemistry and Detrital Modes of Sandstone from Barakar Formation in Mand Valley Basin, Chhattisgarh, India: Implications for Provenance, Tectonic Setting and Paleoweathering", International Journal of Basic and Applied Sciences, Vol. 3, No.2, pp, 124, 2014.

[18] Hussain M., El Hassan W. M., Abdul Raheem, A. "Controls of grain-size distribution on geomechanical properties of reservoir rock-A case study: Cretaceous Khafji Member, Zuluf Field, offshore Arabian Gulf', Marine and Petroleum Geology, Vol. 23 No.6, pp, 703-713, 2006.

[19] Al-Harbi O. A., Khan M. M., "Provenance, diagenesis, tectonic setting and geochemistry of Tawil Sandstone (Lower Devonian) in central Saudi Arabia", Journal of Asian Earth Sciences, Vol. 33 No.3-4, pp, 278-287, 2008.

[20] Folk R. L., "Petrology of Sedimentary Rocks", Hemphill Publishing, Austin, Texas, 1980.
[21] McBride E.F., "A Classification of Common Sandstones", Journal of Sedimentary Petrology Volume, 33, pp, 664-669, 1963.

[22] Dott R. H., "Wacke, Graywacke and Matrix; What Approach to Immature Sandstone Classification?" Journal of Sedimentary Research, Volume, 34, No. 3, pp, 625-632, 1964.

[23] Bhatia M. R., "Plate Tectonics and Geochemical Composition of Sandstones", Journal of Geology, Volume, 91, pp, 611-627, 1983.

[24] Roser B. P., Korsch, R. J., "Determination of Tectonic Setting of Sandstone-Mudstone Suites Using SiO2 Content and K2O/Na2O Ratio", Journal of Geology, Volume, 94, pp, 635-650, 1986.

[25] Roser B. P., Korsch R. J., "Provenance Signatures of Sandstone-Mudstone Suites Determined using Discriminant Function Analysis of MajorElement Data", Chemical Geology, Vol. 67, pp, 119-139, 1988. 